NOTE

\title{
Virus-like particles associated with the apostome ciliate Hyalophysa chattoni
}

\author{
Faye P. Kucera \\ Department of Zoology, North Carolina State University, Raleigh, North Carolina 27695, USA
}

\begin{abstract}
The apostome ciliate Hyalophysa chattoni, an ectosymbiont of the grass shrimp Palaemonetes pugio, lives encysted on its host. Immediately following the host's ecdysis, the ciliate excysts and feeds exclusively on the exuvial fluid within the molt. During this brief time of feeding, the central food vacuole of the ciliate enlarges dramatically. Transmission electron microscopy has revealed the presence of virus-like particles within the central food vacuole in individuals in one molt. Particles appear singly and in clusters scattered throughout the entire food vacuole. No particles are observed within the surrounding cytoplasm. Particles measure $90 \mathrm{~nm}$ in diameter and contain an electron-dense core measuring $65 \mathrm{~nm}$ in diameter. The symbiotic relationship between $H$. chattoni and its shrimp host may provide a means whereby viruses could be transmitted.
\end{abstract}

The complex life cycle of the apostome ciliate Hyalophysa chattoni involves an encysted stage on its shrimp host Palaemonetes pugio. Following the host's ecdysis, the ciliates excyst and feed as trophonts on the exuvial fluid within the molt. During feeding, the central food vacuole enlarges dramatically forcing the cytoplasm to the periphery of the cell. Following feeding, the ciliates have a brief ( 2 to $48 \mathrm{~h}$ ) free-swimming period outside of the molt before they settle on the substrate. They then encyst and divide into infective migratory cells that seek out and encyst on new shrimp hosts thus completing the life cycle (Bradbury 1966) (Fig. 1)

In a study of the ultrastructure of the feeding stage of Hyalophysa chattoni numerous virus-like particles were observed in the central food vacuole of ciliates from a single molt.

Materials and methods. Specimens of the grass shrimp Palaemonetes pugio from the South Creek of the Pamlico River near Aurora, North Carolina, USA, were collected by dip net. Shrimp were maintained in the laboratory in unfiltered aerated tap water adjusted to the proper salinity ( 2 to $5 \mathrm{ppt}$ ) with Instant Ocean Sea Salts (Aquarium Systems Inc., Mentor, $\mathrm{OH}$, USA). Shrimp were fed daily with Tetra-min tropical fish food flakes (TetraWerke, Melle, Germany). Premolt shrimp were isolated into small finger bowls and examined frequently for fresh molts. Ciliates were collected from the molts and transferred into fixative for electron microscopy.

For electron microscopy, ciliates were fixed in $3 \%$ glutaraldehyde in $0.1 \mathrm{M}$ sodium cacodylate at $\mathrm{pH} 7.5$ for $1 \mathrm{~h}$ at room temperature followed by a buffer rinse in $0.05 \mathrm{M}$ sodium cacodylate. Cells were post-fixed in $2 \%$ osmium tetroxide in $0.1 \mathrm{M}$ sodium cacodylate at pH 7.5 for $1 \mathrm{~h}$ at room temperature. Following a buffer rinse in $0.05 \mathrm{M}$ sodium cacodylate buffer, specimens were dehydrated in a graded ethanol series and embedded in Spurr's resin. Ultrathin sections were stained with uranyl acetate and Reynolds lead citrate (Reynolds 1963). Specimens were examined with a JEOL 100 S transmission electron microscope operated at $80 \mathrm{kV}$.

Results. Virus-like particles within the central food vacuole were observed in thin sections of Hyalophysa chattoni trophonts from one molt. Trophonts were otherwise normal in appearance. Particles occur singly and in clusters around electron-dense patches within the central food vacuole. No particles are observed within the cytoplasm of the ciliates (Fig. 4). The particles are spherical (ca $90 \mathrm{~nm}$ in diameter) and are composed of an outer electron-dense layer $5 \mathrm{~nm}$ in width, a less electron-dense layer $10 \mathrm{~nm}$ in width, and an electrondense core measuring $65 \mathrm{~nm}$ in diameter (Fig. 5) 

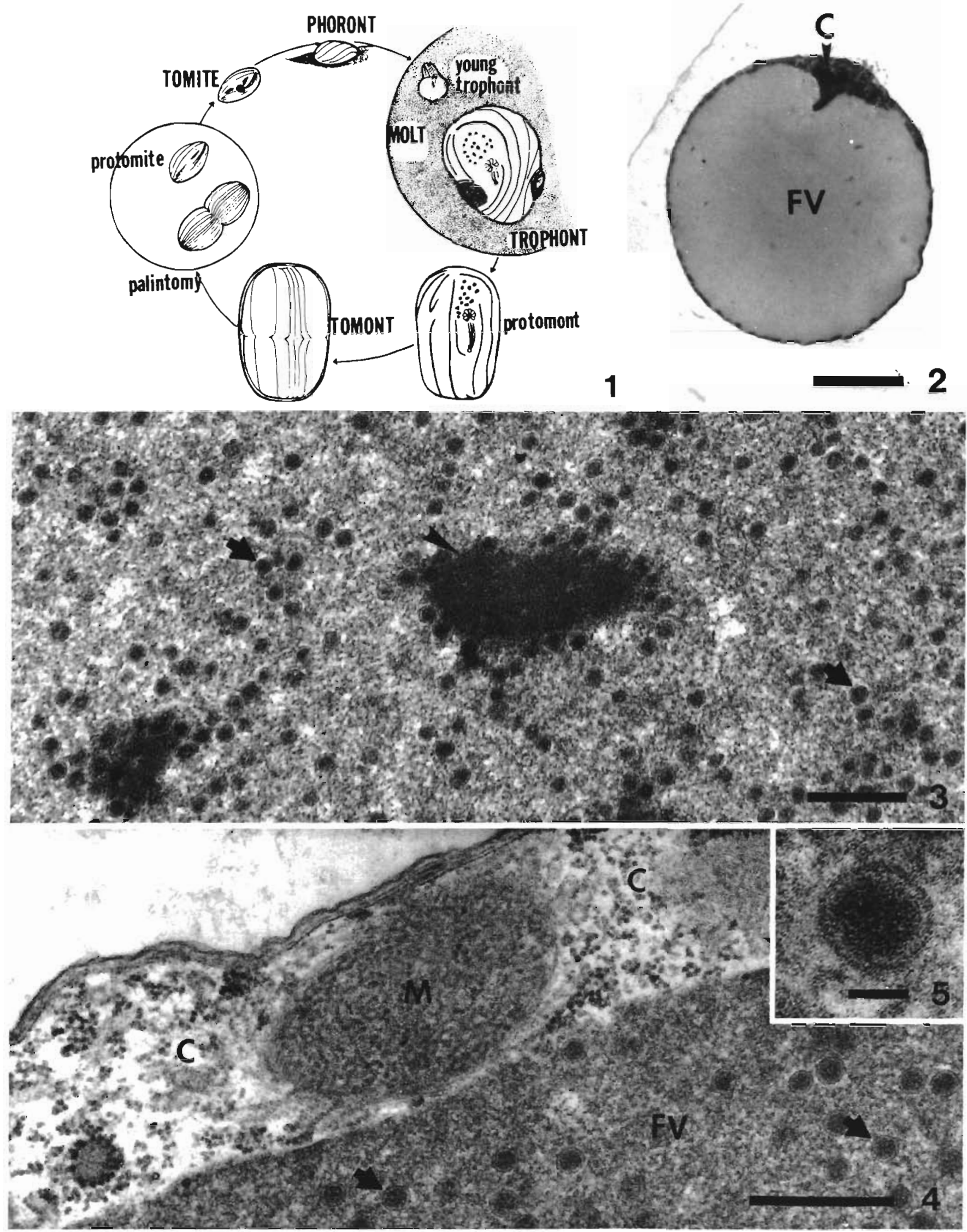
Figs. 1 to 5. Hyalophysa chattoni. Fig. 1. Life cycle (after Bradbury 1966). Fig. 2. Cross-section through a trophont. The cytoplasm (C) is restricted to the darker staining narrow rim surrounding the central food vacuole (FV). Bar $=5 \mu \mathrm{m}$. Fig. 3 . Transmission electron micrograph of the central food vacuole of a trophont. Virus-like particles (arrows) are scattered throughout the entire food vacuole and are often found concentrated around electron-dense patches (arrowhead). Bar $=0.5 \mu \mathrm{m}$. Fig. 4 . Transmission electron micrograph of a trophont. Virus-like particles (arrows) are seen scattered throughout the food vacuole (FV). Note that no particles are present within the surrounding rim of cytoplasm (C). M: mitochondrion. Bar $=0.5 \mu \mathrm{m}$. Fig. 5 . Transmission electron micrograph of virus-like particle. Particle is composed of an outer electron-dense layer, an inner less electron-dense layer, and an electrondense core. $\mathrm{Bar}=50 \mu \mathrm{m}$

Discussion. The presence of numerous virus-like particles found exclusively in the central food vacuole of Hyalophysa chattoni suggests that the ciliates acquired them while feeding on the exuvial fluid released by an infected host when it molted. Earlier Rivaud (1986) reported the presence of numerous intact bacteria in the central food vacuole of $H$. chattoni from several molts and postulated that these bacteria were acquired from the exuvial fluid of heavily infected shrimp. The particles described here differ markedly in size and shape from these bacteria and are in the size range of viruses. The size and morphology of the virus-like particles suggest that they may be bunyaviruses. Perhaps the particles in the exuvial fluid resulted from the rupture of virus-infected hypodermal cells at molting. A hypodermal viral infection has been reported by Lightner et al. (1983) in the Pacific blue shrimp Penaeux stylirostris. Small (17 to $27 \mathrm{~nm}$ ) viruslike particles were observed in the cuticular hypodermis as well as in the hemocytes, hematopoietic organs, and connective tissues.

Ciliates could possibly collect substantial numbers of virus-like particles by feeding on the exuvial fluid of an infected shrimp. Following feeding and a brief ( 2 to

Responsible Subject Editor: J. E. Stewart, Dartmouth, N.S., Canada
$48 \mathrm{~h}$ ) free-swimming period outside of the molt, the ciliates settle on the substrate at some distance from the molt. Palaemonetes pugio feeds on detrital fragments on the substrate and therefore may consume encysted ciliates indirectly. As a result, carrier Hyalophysa chattoni could then be consumed by another shrimp and thus provide a possible means of passive transmission of the virus from shrimp to shrimp.

\section{LITERATURE CITED}

Bradbury, P. C. (1966) The life cycle and morphology of the apostomatous ciliate Hyalophysa chattoni n. g., n. sp. J. Protozool. 13: 209-225

Lightner, D. V., Redman, R. M., Bell, T A. (1983). Infectious hypodermal and hematopoietic necrosis, a newly recognized virus disease of penaeid shrimp. J. Invertebr. Pathol 42: $62-70$

Reynolds, E. (1963). The use of lead citrate at high $\mathrm{pH}$ as an electron-opaque stain in electron microscopy. J. Cell Biol $17: 208-212$

Rivaud, N. I. (1986). Light and electron microscopic study of the nuclear and cytoplasm changes concurrent with encystation and division in the apostome Hyalophysa chattoni. Ph.D. dissertation, North Carolina State University, Raleigh

Manuscript first received: August 14, 1991

Revised version accepted: December 12, 1991 